\title{
COMPETITIVENESS OF THE WIELKOPOLSKA REGION IN TERMS OF A KNOWLEDGE-BASED ECONOMY
}

\author{
TERESA CZYŻ \\ Adam Mickiewicz University, Institute of Socio-Economic Geography and Spatial Management, \\ Poznań, Poland \\ Manuscript received May 12, 2010 \\ Revised version June 7, 2010
}

CZYŻ T., Competitiveness of the Wielkopolska region in terms of a knowledge-based economy. Quaestiones Geographicae 29(2), Adam Mickiewicz University Press, Poznań 2010, pp. 71-84, 1 Fig., 7 Tables. ISBN 978-83-2322168-5. ISSN 0137-477X. DOI 10.2478/v10117-010-0015-4.

\begin{abstract}
In the study of the competitiveness of the Wielkopolska region it is assumed that in modern times the foundation of a competitive advantage is a knowledge-based economy (KBE). The aim of the article is to analyse the competitiveness of the Wielkopolska region (voivodeship) in terms of KBE in comparison with the country's regional system. Four dimensions of the region's competitiveness are distinguished, representing factors of KBE development and effects of their operation in the economic sphere. With the help of principal components analysis, indices of the region's competitiveness are obtained.
\end{abstract}

KEYWORDS: knowledge-based economy, region's competitiveness, dimensions of competitiveness, principal components analysis, Wielkopolska region

Teresa Czyż, Institute of Socio-Economic Geography and Spatial Management, Adam Mickiewicz University, ul. Dzięgielowa 27,61-680 Poznań, Poland; e-mail: tczyz@amu.edu.pl

\section{Introduction}

In the recent years, a subject of special interest to regional studies has been the competitiveness of regions. The marked animation in this field of research has clearly been the effect of the new regional policy of the European Union with its top priority of enhancing the competitiveness of regions treated as a driving force of regional development.

The socio-economic region is the place where a competitive advantage is being formed in a globalising economy. It is assumed that the competitiveness of a region is a means (instrument) of attaining the general social goal of development, viz. an increase in regional income and wealth.

The aim of the present article is to analyse the competitiveness of the region (voivodeship) of Wielkopolska in terms of a knowledge-based economy as compared with the rest of the regional system of Poland ${ }^{1}$. A start is made by discussing the conception of the competitiveness of regions.

\footnotetext{
${ }^{1}$ It is assumed that a voivodeship is more than an administrative unit, i.e. that it is a territorial socio-economic region, or a territorial subsystem of the state integrating and organising the social, economic and cultural activity of its residents in territorial terms.
} 
Competitiveness is a mechanism that determines the behaviour of enterprises in a market economy. This also refers to the economic development of states and regions. Hence, there has appeared a conception of the competitiveness of states and regions as embracing those market-determined properties of their economies that affect the level of their development.

While deriving from the conception of the competitiveness of states presented by Porter (1990), that of the competitiveness of regions concerns different aspects of economic development, which stems from a different status of regions as territorial social subsystems of the state (Chojnicki \& Czyż 2005: 16).

In the literature on the subject, the competitiveness of a region is defined as follows: it is its ability to adjust to the changing economic, social and environmental challenges and tasks, as well as its ability to create new conditions (opportunities) of development that allow the region to keep or reinforce its position in the national or international system (Winiarski 1999: 9; Gaczek \& Rykiel 2000: 113; Markowski 2005: 25; Ratajczak 2007: 840)².

In the process of adjustment to change, one of such challenges for a region posed by the character of present-day socio-economic development is the emergence of a knowledge-based economy (KBE). What is considered the chief aspect of modernisation of the economy and enhancement of its competitiveness is an increase in the share of $\mathrm{KBE}$ in it.

The opinion increasingly gaining ground in the theory of regional development is that the traditional development factors - land and mineral resources, labour and capital - tend to give way to knowledge. The part of the economy that predominantly develops under the influence of science is known as KBE.

${ }^{2}$ The notion of the competitiveness of regions as formulated by Gaczek and Rykiel (2000: 114) is often associated with the adaptation of regions, and more precisely with effective adaptation and adaptability. Effective adaptation is the adjustment of a region to changes in the socio-economic system that brings about certain social and economic effects and that can assume the form of adaptability, i.e. a permanent adaptive ability (Stryjakiewicz 1999: 38). The difference between the adaptation and the competitiveness of the region, therefore, is that adaptation only means its ability to adapt to changes, while competitiveness presupposes a relative character of the adaptation, which can lead to an advantage of the region over other regions.
$\mathrm{KBE}$ can be given a narrower or a wider sense. In the former, the term refers to (1) high-tech manufacturing and services, i.e. sections of the economy employing the most advanced technologies in the production process, in particular information and communications technology (ICT), and (2) traditional industries manufacturing new and much improved products. In the wider sense, $\mathrm{KBE}$ is also seen as including educational, financial, medical and administrative services modified and performed within the framework of applied sciences (Chojnicki \& Czyż 2006: 20).

KBE development means changes in the character of the economy that embrace two parallel fields: (1) new branches of the economy producing ICT equipment and services, and (2) new technological applications in the traditional branches. A result is a rise in the demand for new ICT equipment and programmes that mould the structure of an information society. There is also a change in the organisational and institutional structures of the economy, especially of the commodity and financial markets as well as the business environment (Woroniecki 2001).

The character and pattern of KBE development in a region are determined by several factors. Chief among them are human and social capital, R\&D and innovativeness, physical infrastructure, in particular in the form of information and communications technology, and institutional-organisational factors. KBE rests on research and development activity as well as innovations; they lead to the modernisation of the economy and an increase in productivity, which in turn governs the level of income generated. Human and social capital is both a source of innovative knowledge and a potential link transmitting it to the economy.

Accommodating the role of KBE in competitiveness offers a new insight into this concept as conceived by Porter's (2001) classical theories. The competitiveness of a region is seen in terms of KBE: it rests on the region's ability to create and employ factors that determine the appearance and development of KBE. Thus, factors of KBE development are interpreted as factors of the region's competitiveness (Huggins \& Davies 2006: 1). The region's competitiveness is considered not only with reference to potential factors of KBE development, but also in terms of their 
efficient use that leads to certain benefits in economic and social activity, and those, in turn, to the region's advantage over other regions. As to the benefits, their extent is determined by an above-average level of production, productivity, exports, investment, and regional income.

As follows from the above, a high share of $\mathrm{KBE}$ in the economy of a region is regarded as the principal and effective source of the region's competitiveness.

\section{Empirical analysis of a region's competitiveness}

The aim of the empirical analysis of the competitiveness of regions in Poland, in particular of the Wielkopolska region, was to find how far $\mathrm{KBE}$ contributed to their competitiveness.

In empirical research on competitiveness, one has first to identify those economic and social characteristics of a region that decide about its advantage over other regions and determine its competitiveness. The choice of those characteristics (variables) and the identification of their groupings, henceforth called dimensions, rests on the perception of competitiveness in terms of factors of competitiveness and the advantages they bring the region (Gardiner et al., 2004: 1048).

The chief factors determining the competitiveness of a region perceived in terms of KBE are human and social capital as well as the capital of applied knowledge. Treated as equivalents of factors of KBE development, they constitute the first and second dimensions of the competitiveness of the region.

The third dimension describes physical infrastructure endowment and the new economy associated with the state of KBE in the region, and is treated as a dimension representing the third factor of the region's competitiveness. It is argued that the share KBE has reached in the economy of the region has a significant influence on its competitiveness. This effect is not restricted to an increase in productivity brought about by KBE-related activity; it also gives other sectors of the regional economy new growth impulses.

The fourth dimension of the region's competitiveness is that of economic advantages associated with competitiveness and measured by employment, productivity of labour, exports, foreign investment, and regional income (Klasik 2003: 63-64, Kitson et al. 2004: 995, Biniecki \& Frenkiel 2005: 34).

In the next step of the research procedure, four variable groupings corresponding to the four dimensions of competitiveness undergo a reduction with the help of principal components analysis (Maćkiewicz \& Ratajczak 1993; Ratajczak 2008). It involves a mathematical transformation of the empirical variables to identify components, or meta-variables. Those components are derived from each of the individual variable groupings that constitute the four dimensions of the region's competitiveness (designated A, B, C and $\mathrm{D})$, and from an analysis of the variables in a multidimensional (three- and four-dimensional) approach $(\mathrm{A}+\mathrm{B}+\mathrm{C}$ and $\mathrm{A}+\mathrm{B}+\mathrm{C}+\mathrm{D})$.

The values of the components of the individual dimensions are partial indices of the competitiveness of regions, while the values of the components obtained in the multidimensional approach are synthetic indices. As a result, differences in the level of the competitiveness of regions are determined on the scales of values of partial and synthetic indices of competitiveness.

\section{Competitiveness of the Polish regions}

An analysis of the competitiveness of Wielkopolska is preceded by a ranking of all the regions (voivodeships) of Poland for competitiveness.

The research procedure starts with regional data containing the values of 48 socio-economic variables for the 16 regions (voivodeships). They are divided into groups of variables referring to the four dimensions of competitiveness in the adopted model of a region's competitiveness. Three dimensions represent factors of competitiveness in KBE terms: (A) human capital and social capital, (B) capital of applied knowledge, and $(C)$ infrastructure endowment and the new economy. The fourth (D) is the dimension of economic performance as an effect of the region's

${ }^{3}$ The data mostly concern the years 2005-2007 and come from the Central Statistical Office's (GUS) Statistical Yearbooks of Voivodeships and from Eurostat. An exception is the 2002 information about the population with higher education (GUS). 
TABLE 1. DiMENSIONS OF THE COMPETITIVENESS OF REGIONS

\begin{tabular}{|c|}
\hline A. Human and social capital \\
\hline $\begin{array}{l}\text { 1. Working population as } \% \text { of total population } \\
\text { 2. Proportion of working population in the number of population aged } 15 \text { and older } \\
\text { 3. Proportion of population with higher education } \\
\text { 4. Students per } 10,000 \text { population } \\
\text { 5. University graduates who took up their first work in } 2007 \text { as } \% \text { of total employment } \\
\text { 6. Number of persons engaged in a lifelong learning programme per } 1,000 \text { population } \\
\text { 7. Natural persons engaged in economic activity per } 10,000 \text { population } \\
\text { 8. Non-governmental social organisations per } 10,000 \text { population } \\
\text { 9. Proportion of investment outlays in communes' total budgetary expenditure } \\
\text { 10. EU IOPRD funds granted for the years } 2004-2006 \text { as } \% \text { of domestic means } \\
\text { 11. Proportion of commune offices providing electronic services at high level of interactivity } \\
\text { 12. Support for Poland's accession to the EU ( } \% \text { of 'yes' votes in the referendum) } \\
\text { 13. Voter turnout in elections of commune councillors ( } \% \text { of eligible voters) }\end{array}$ \\
\hline B. Capital of applied knowledge \\
\hline $\begin{array}{l}\text { 14. Employment in R\&D per } 1,000 \text { working population } \\
\text { 15. Human resources in science and technology as } \% \text { of total population } \\
\text { 16. Outlays for R\&D per person (in zlotys) } \\
\text { 17. Outlays for R\&D as \% of GDP } \\
\text { 18. Scientific activity of the R\&D sector } \\
\text { 19. Innovation and entrepreneurship centres per } 10,000 \text { population } \\
\text { 20. Enterprises engaged in innovative activity as } \% \text { of industrial enterprises }\end{array}$ \\
\hline C. Infrastructure endowment and the new economy \\
\hline $\begin{array}{l}\text { 21. Density of electrified standard-gauge rail lines per } 100 \mathrm{~km}^{2} \\
\text { 22. Public roads per } 100 \mathrm{~km}^{2} \text { (in } \mathrm{km} \text { ) } \\
\text { 23. Cars per } 1,000 \text { population } \\
\text { 24. Proportion of households with personal computers with Internet access } \\
\text { 25. Proportion of employment in very high-tech manufacturing and high-tech services (HTMh and HTS) } \\
\text { 26. Proportion of employment in high-tech manufacturing (HTM) } \\
\text { 27. Proportion of employment in very high-tech manufacturing (HTMh) } \\
\text { 28. Proportion of employment in knowledge-intensive services (KIS) } \\
\text { 29. Proportion of employment in high-tech services (HTS) } \\
\text { 30. Proportion of employment in business services (KIMS) } \\
\text { 31. Proportion of employment in financial services (KIFS) } \\
\text { 32. Proportion of employment in health-care, education and media industry services (OKIS) } \\
\text { 33. Number of big KBE enterprises } \\
\text { 34. Big KBE enterprises as \% of total number of big enterprises } \\
\text { 35. Employment in big KBE enterprises as \% of employment in big enterprises } \\
\text { 36. Productivity of big KBE firms in region as compared with average for big KBE firms in Poland }\end{array}$ \\
\hline D. Economic performance \\
\hline $\begin{array}{l}\text { 37. Per capita GDP (in thous. zlotys) } \\
\text { 38. Increase in per capita GDP (2005-2006) } \\
\text { 39. Gross value added per employee (in thous. zlotys) } \\
\text { 40. Increase in gross value added per employee (2005-2006) } \\
\text { 41. Workers per } 1,000 \text { population } \\
\text { 42. Rate of wage increase to employment increase (2000-2007) } \\
\text { 43. Exports per person (in thous. euro) } \\
\text { 44. Exports to } 26 \text { EU states per person (in thous. euro) } \\
\text { 45. Foreign capital per } 10,000 \text { population (in million zlotys) } \\
\text { 46. Companies with foreign capital participation per } 10,000 \text { population } \\
\text { 47. Share capital per company with foreign capital participation (in million zlotys) } \\
\text { 48. Index of foreign capital growth dynamics in the years } 2004-2007\end{array}$ \\
\hline
\end{tabular}


TABLE 2. COEFFICIENTS OF CORRELATION* OF THE FIRST COMPONENTS WITH THE VARIABLES OF THE COMPETITIVENESS DIMENSIONS

\begin{tabular}{|c|c|c|c|c|c|c|}
\hline Variable & $\mathbf{V}_{1 \mathrm{~A}}$ & $\mathbf{V}_{1 \mathrm{~B}}$ & $\mathbf{V}_{1 \mathrm{C}}$ & $\mathbf{V}_{1 \mathrm{D}}$ & $V_{1(\mathrm{ABC})}$ & $\mathrm{V}_{1(\mathrm{ABCD})}$ \\
\hline 3. Proportion of population with higher education & 0.93 & & & & 0.90 & 0.88 \\
\hline 4. Students per 10,000 population & 0.85 & & & & 0.78 & 0.76 \\
\hline $\begin{array}{l}\text { 5. University graduates who took up their first work in } \\
2007 \text { as \% of total employment }\end{array}$ & 0.85 & & & & 0.86 & 0.87 \\
\hline $\begin{array}{l}\text { 6. Number of persons engaged in a lifelong learning pro- } \\
\text { gramme per } 1,000 \text { population }\end{array}$ & 0.80 & & & & 0.75 & 0.74 \\
\hline $\begin{array}{l}\text { 8. Non-governmental social organisations per } 10,000 \text { popu- } \\
\text { lation }\end{array}$ & 0.67 & & & & 0.73 & 0.73 \\
\hline $\begin{array}{l}\text { 9. Proportion of investment outlays in communes' total } \\
\text { budgetary expenditure }\end{array}$ & 0.84 & & & & 0.89 & 0.90 \\
\hline $\begin{array}{l}\text { 10. EU IOPRD funds granted for the years } 2004-2006 \text { as \% of } \\
\text { domestic means }\end{array}$ & 0.73 & & & & 0.72 & 0.71 \\
\hline 14. Employment in R\&D per 1,000 working population & & 0.96 & & & 0.93 & 0.92 \\
\hline $\begin{array}{l}\text { 15. Human resources in science and technology as \% of total } \\
\text { population }\end{array}$ & & 0.85 & & & 0.90 & 0.88 \\
\hline 16. Outlays for R\&D per person (in zlotys) & & 0.97 & & & 0.91 & 0.89 \\
\hline 17. Outlays for R\&D as \% of GDP & & 0.93 & & & 0.80 & 0.75 \\
\hline $\begin{array}{l}\text { 24. Proportion of households with personal computers with } \\
\text { Internet access }\end{array}$ & & & 0.81 & & 0.68 & 0.67 \\
\hline $\begin{array}{l}\text { 25. Proportion of employment in very high-tech manufac- } \\
\text { turing and high-tech services (HTMh and HTS) }\end{array}$ & & & 0.95 & & 0.95 & 0.94 \\
\hline $\begin{array}{l}\text { 27. Proportion of employment in very high-tech manufac- } \\
\text { turing }(\mathrm{HTMh})\end{array}$ & & & 0.75 & & 0.64 & 0.64 \\
\hline $\begin{array}{l}\text { 28. Proportion of employment in knowledge-intensive serv- } \\
\text { ices (KIS) }\end{array}$ & & & 0.90 & & 0.89 & 0.87 \\
\hline 29. Proportion of employment in high-tech services (HTS) & & & 0.89 & & 0.93 & 0.92 \\
\hline 30. Proportion of employment in business services (KIMS) & & & 0.82 & & 0.72 & 0.73 \\
\hline 31. Proportion of employment in financial services (KIFS) & & & 0.69 & & 0.72 & 0.75 \\
\hline 33. Number of big KBE enterprises & & & 0.75 & & 0.86 & 0.88 \\
\hline $\begin{array}{l}\text { 34. Big KBE enterprises as \% of total number of big enter- } \\
\text { prises }\end{array}$ & & & 0.63 & & 0.62 & 0.62 \\
\hline $\begin{array}{l}\text { 35. Employment in big KBE enterprises as \% of employment } \\
\text { in big enterprises }\end{array}$ & & & 0.71 & & 0.64 & 0.62 \\
\hline 37. Per capita GDP (in thous. zlotys) & & & & 0.95 & & 0.94 \\
\hline 39. Gross value added per employee (in thous. zlotys) & & & & 0.90 & & 0.80 \\
\hline 43. Exports per person (in thous. euro) & & & & 0.84 & & 0.71 \\
\hline 44. Exports to 26 EU states per person (in thous. euro) & & & & 0.80 & & 0.64 \\
\hline 45. Foreign capital per 10,000 population (in million zlotys) & & & & 0.86 & & 0.88 \\
\hline $\begin{array}{l}\text { 46. Companies with foreign capital participation per } 10,000 \\
\text { population }\end{array}$ & & & & 0.86 & & 0.80 \\
\hline
\end{tabular}

* Coefficients of correlation $r \geq 0.62$, statistically significant at the $\alpha=0.01$ level and with (16-2) degrees of freedom. Source: own compilation. 
competitiveness (Table1). Thenumber of variables in the groups varies, which is not connected with the weight of the given dimension in the competitiveness model, but with the availability of statistical data. Group A contains 13 variables, group $B-7$, group $C-16$, and group $D-12$.

A separate principal components analysis based on a correlation matrix is carried out for each of the four groups of variables ${ }^{4}$. Out of the principal components only the first, $\mathrm{V}_{1}$, is chosen as one accounting for the highest proportion of the total variance of the original variables. In the groups of variables, the first components account for: $\mathrm{V}_{1 \mathrm{~A}}-42 \%, \mathrm{~V}_{1 \mathrm{~B}}-60 \%, \mathrm{~V}_{1 \mathrm{C}}-47 \%$, and $\mathrm{V}_{1 \mathrm{D}}-47 \%$ of the total variance.

The component is a meta-variable associated with a specified dimension of competitiveness; it is its index. As an index of a dimension of competitiveness, the component only refers to a specified facet of this dimension, i.e. it displays significant correlations with only a few variables of this dimension (Table 2). The interpretation of the components, i.e. indices of the individual dimensions of a region's competitiveness, looks as follows: component $\mathrm{V}_{1 \mathrm{~A}}$ - human and social capital, in terms of universality of higher education and activity of the regional community; component $\mathrm{V}_{1 \mathrm{~B}}$ - the capital of applied knowledge, in terms of research and development activity; component $\mathrm{V}_{1 \mathrm{C}}$ - infrastructure endowment and the new economy, in terms of the knowledge-based economy; and component $\mathrm{V}_{1 \mathrm{D}}$ - economic performance, in terms of regional income, productivity of labour, exports, and foreign capital. In the further research procedure, the components of the individual dimensions of competitiveness (A - D) are called partial indices, with each referring to one of the four dimensions of competitiveness.

In turn, synthetic indices of competitiveness are determined on the basis of: (1) the principal components analysis of 36 variables describing the three dimensions of competitiveness corresponding to factors constituting the competitive potential of the 16 regions in terms of $\mathrm{KBE}$; the first component, $\mathrm{V}_{1(\mathrm{ABC})}$, accounts for $44 \%$ of the total variance of variables; and (2) the principal components analysis of the entire set of 48

${ }^{4}$ The principal components analysis and multiple regression programs were designed and run by Jan Hauke. variables describing the competitiveness of the 16 regions in the four dimensions; here the first component, $\mathrm{V}_{1(\mathrm{ABCD})^{\prime}}$ accounts for $43 \%$ of the total variance. Components $\mathrm{V}_{1(\mathrm{ABC})}$ and $\mathrm{V}_{1(\mathrm{ABCD})}$ have a specific internal structure: they 'contain' all the significant empirical variables 'building' the components that are partial indices (Table 2). In the case of component $\mathrm{V}_{1(\mathrm{ABC})}$ ' this 'input' embraces 21 variables, and in the case of component $\mathrm{V}_{1(\mathrm{ABCD})^{\prime}}$ 27 variables (Table 2). Therefore components $\mathrm{V}_{1(\mathrm{ABC})}$ and $\mathrm{V}_{1(\mathrm{ABCD})}$ can be treated as synthetic indices of the competitiveness of regions.

The values of the components $\left(\mathrm{w}_{1}\right)$ calculated for the 16 regions as the values of the partial indices and the synthetic indices provide a basis for a classification of the regions on the scale of competitiveness (Table 3 ).

'Being competitive' is taken as determined by the criterion of above-average values of the synthetic indices and at least three out of the four partial indices of competitiveness ${ }^{5}$.

By this criterion, the class of competitive regions includes seven voivodeships: Mazovia, Lower Silesia, Pomerania, Silesia, Małopolska, Wielkopolska, and Łódź; the remaining regions are eliminated from further analysis as noncompetitive. Worth noting is the fact that only regions with large urban agglomerations belong to the class (Table 4).

The seven regions distinguished display wide differences in their levels of competitiveness.

On the scale of the synthetic index of threedimensional competitiveness, or the index of the competitive potential of regions (formed by the competitiveness factors), the clearly predominating region is Mazovia (Table 4): its $\mathrm{w}_{1(\mathrm{ABC})}$ index is three times that of the region coming second. Lower Silesia and Pomerania, second and third respectively, show relatively high $\mathrm{w}_{1(\mathrm{ABC})}$ figures in comparison with the remaining four regions. In Małopolska and Silesia, which come fourth and fifth, the index values are similar but low, while Łódź and Wielkopolska, sixth and seventh, have the lowest $\mathrm{w}_{1(\mathrm{ABC})}$ indices.

The ordering of the regions on the scale of the second synthetic index, of four-dimensional competitiveness, $\mathrm{w}_{1(\mathrm{ABCD})^{\prime}}$ which additionally accommodates the dimension of economic per-

\footnotetext{
${ }^{5}$ Those values are standardised, hence the above-average values are greater than zero.
} 


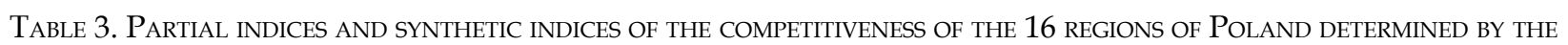
PRINCIPAL COMPONENTS METHOD

\begin{tabular}{|c|c|c|c|c|c|c|}
\hline \multirow{2}{*}{ Region } & \multicolumn{6}{|c|}{ Values of the first component $w 1$} \\
\hline & w1A & w1B & w1C & w1D & w1(ABC) & w1(ABCD) \\
\hline Lower Silesia & 0.93 & 0.54 & 1.00 & 1.37 & 0.94 & 1.08 \\
\hline Kujavia-Pomerania & 0.88 & -0.43 & 0.39 & -0.23 & 0.52 & -0.50 \\
\hline Lublin & 0.05 & -0.13 & 0.94 & -1.28 & 0.81 & -0.72 \\
\hline Lubuska Land & -0.64 & -1.05 & -0.76 & 0.20 & 0.58 & -0.58 \\
\hline Łódź & 0.45 & 0.16 & 0.04 & -0.36 & 0.16 & 0.04 \\
\hline Małopolska & 0.48 & 1.32 & 0.38 & -0.17 & 0.65 & 0.46 \\
\hline Mazovia & 2.97 & 2.92 & 2.23 & 2.54 & 2.77 & 2.81 \\
\hline Opole & -1.36 & -0.58 & -0.51 & -0.66 & -0.77 & -0.76 \\
\hline Subcarpathia & -0.77 & -0.57 & -0.62 & -1.16 & -0.76 & -0.86 \\
\hline Podlasie & -0.58 & -0.75 & -0.94 & -1.07 & -0.81 & -0.89 \\
\hline Pomerania & 0.36 & 0.39 & 1.47 & 0.45 & 0.91 & 0.80 \\
\hline Silesia & 0.06 & 0.18 & 0.95 & 0.62 & 0.51 & 0.54 \\
\hline Świętokrzyska Land & -0.48 & -0.91 & -1.28 & -0.53 & -1.04 & -0.91 \\
\hline Warmia-Mazuria & -0.66 & -0.71 & -0.92 & -0.55 & -0.77 & -0.77 \\
\hline Wielkopolska & 0.08 & 0.14 & 0.06 & 0.76 & 0.06 & 0.24 \\
\hline West Pomerania & -0.01 & -0.50 & 0.23 & 0.05 & 0.05 & 0.03 \\
\hline
\end{tabular}

Source: own calculations and compilation.

TABLE 4. RANKING OF THE COMPETITIVE REGIONS

\begin{tabular}{|c|c|c|c|c|c|c|c|c|c|c|c|c|}
\hline \multirow{2}{*}{ Region } & \multicolumn{12}{|c|}{ Indices of competitiveness } \\
\hline & $\mathbf{w}_{1(\mathrm{ABCD})}$ & rank & $w_{1(\mathrm{ABC})}$ & rank & $w_{1 A}$ & rank & $\mathbf{w}_{1 \mathrm{~B}}$ & rank & $\mathbf{w}_{1 \mathrm{C}}$ & rank & $\mathbf{w}_{1 \mathrm{D}}$ & rank \\
\hline Mazovia & 2.81 & 1 & 2.77 & 1 & 2.97 & 1 & 2.92 & 1 & 2.23 & 1 & 2.54 & 1 \\
\hline Lower Silesia & 1.08 & 2 & 0.94 & 2 & 0.93 & 2 & 0.54 & 3 & 1.00 & 3 & 1.37 & 2 \\
\hline Pomerania & 0.80 & 3 & 0.91 & 3 & 0.36 & 5 & 0.39 & 4 & 1.47 & 2 & 0.45 & 5 \\
\hline Silesia & 0.54 & 4 & 0.51 & 5 & 0.06 & 7 & 0.18 & 5 & 0.95 & 4 & 0.62 & 4 \\
\hline Małopolska & 0.46 & 5 & 0.65 & 4 & 0.48 & 3 & 1.32 & 2 & 0.38 & 5 & -0.17 & 6 \\
\hline Wielkopolska & 0.24 & 6 & 0.06 & 7 & 0.08 & 6 & 0.14 & 7 & 0.06 & 6 & 0.76 & 3 \\
\hline Łódź & 0.04 & 7 & 0.16 & 6 & 0.45 & 4 & 0.16 & 6 & 0.04 & 7 & -0.36 & 7 \\
\hline
\end{tabular}

Source: own calculations and compilation. 
formance, looks as follows (Tables 4). The positions of Mazovia, Lower Silesia and Pomerania do not change, while the remaining regions move one position up or down the scale: Małopolska from 4th to 5th, Łódź from 6th to 7th, Silesia from 5th to 4th, and Wielkopolska from 7th to 6th.

A change in the position of a region on the scale of the $W_{1(A B C D)}$ index from its position on the $\mathrm{w}_{1(\mathrm{ABC})}$ scale is indicative of the character of the relationship between its competitive potential in terms of KBE and its economic performance seen in the analysis as the effects of competitiveness.

To elucidate those relations, a statistical dependence was calculated for the seven regions between the competitiveness factors (competitive potential) and economic performance using the multiple regression method. A regression model with three independent variables was formulated:

$$
\mathrm{w}_{1 \mathrm{D}, \mathrm{j}}=\mathrm{b}_{0}+\mathrm{b}_{1} \mathrm{w}_{1 \mathrm{~A}, \mathrm{j}}+\mathrm{b}_{2} \mathrm{w}_{1 \mathrm{~B}, \mathrm{j}}+\mathrm{b}_{3} \mathrm{w}_{1 \mathrm{C}, \mathrm{j}}
$$

where:

$\mathrm{w}_{1 \mathrm{D}, \mathrm{j}}=\mathrm{a}$ partial index of economic performance $w_{1 D}$ in region $j, j=1,2,3, \ldots, 7$.

As a result of the estimation of the model parameters using the stepwise regression method, the following equation was obtained:

$$
\begin{array}{r}
\mathrm{w}_{1 \mathrm{D}, \mathrm{j}}=0.1465+0.7851 \mathrm{w}_{1 \mathrm{~A}, \mathrm{j}}, \\
\mathrm{R}^{2}=66 \% \text { significant at } \alpha=0.0260,
\end{array}
$$

which means that economic performance displays a statistically significant relation with only one of the factors of competitiveness, viz. human and social capital $\left(\mathrm{w}_{1 \mathrm{~A}}\right)$. On the basis of the estimated equation, the following can be established.

(1) There is a proportional relationship between human and social capital as a competitiveness factor and the economic performance of the regions of Mazovia and Pomerania: the higher the human and social capital, the more pronounced the economic effect.

(2) Regional deviations from this dependence are determined by residuals from regression (Table 5). Significant negative residual values are displayed by regions that have a relatively low level of economic performance in relation to their human and social capital. Those are Małopolska and Łódź, which do not make full use of the possibilities that human and social capital can offer in the process of development. In turn, a relative 'surplus' of the effects (positive residuals) over human and social capital is characteristic of Wielkopolska, Lower Silesia and Silesia. Those regions show a higher level of economic effects of their competitiveness than would follow from its link with KBE as represented by human and social capital. This can also be due to the fact that only some of the economic effects accommodated in the model can be qualified as produced by KBE-related competitiveness.

The distribution of the regional residuals from regression calls for the introduction into the regression equation of further factors producing economic effects. This, however, needs a continued modelling of the dependence.

TABLE 5. RESIDUALS FROM REGRESSIONDEPTHS

\begin{tabular}{|l|c|c|c|}
\hline \multicolumn{1}{|c|}{ Region } & $\mathbf{w}_{1 \mathrm{D}}$ & $\hat{\mathbf{w}}_{\mathbf{1 D}}$ & $\mathbf{w}_{\mathbf{1 D}}-\hat{\mathbf{w}}_{\mathbf{1 D}}$ \\
\hline Mazovia & 2.54 & 2.4781 & 0.0619 \\
\hline Lower Silesia & 1.37 & 0.8766 & 0.4934 \\
\hline Pomerania & 0.45 & 0.4291 & 0.0209 \\
\hline Silesia & 0.62 & 0.1936 & 0.4264 \\
\hline Małopolska & -0.17 & 0.5233 & -0.6933 \\
\hline Wielkopolska & 0.76 & 0.2093 & 0.5507 \\
\hline Łódź & -0.36 & 0.4998 & -0.8598 \\
\hline
\end{tabular}

Source: own calculations and compilation.

\section{Competitiveness of the Wielkopolska region}

The level of the competitiveness of Wielkopolska is characterised in comparison with the remaining six regions of Poland put into the class of competitive regions (Fig. 1).

Wielkopolska has a low, sixth position in the regional ranking by four-dimensional competitiveness (Table 4). This is due to its relatively low competitive potential, which includes three factors: human and social capital, the capital of applied knowledge, as well as infrastructure endowment and the new economy.

The elements of human and social capital that clearly differentiate the regions are: (a) universality of higher education, which embraces the following variables: population with higher education (variable 3), students (4), employment 


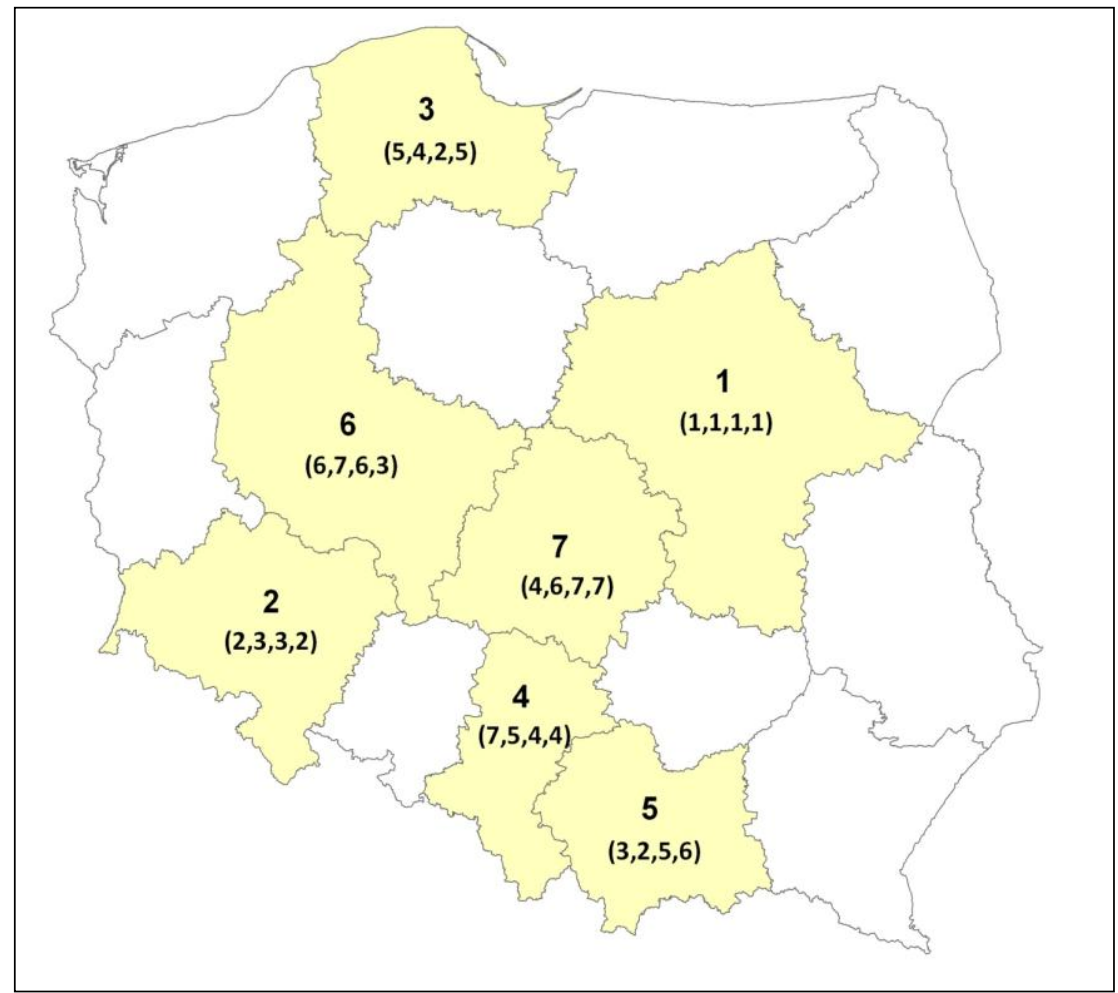

Fig. 1. The competitive regions*

* $1(1,1,1,1)$ denotes first position on the scale of four-dimensional competitiveness and first position on the scales of the four individual dimensions of competitiveness

of university graduates (5), and lifelong learning (6); and (b) social and economic activity, with its three variables: non-governmental social organisations (8), investment outlays in communes (9), and EU assistance funds (10) (Table 2). The index of human and social capital for Wielkopolska (0.08) is much lower than in the region with the highest value of this index, viz. Mazovia (2.97) (Table 4) and only gives Wielkopolska sixth place, before Silesia. In the light of the statistical data, this dimension of competitiveness of the Wielkopolska region looks as follows (Table 6). The proportion of the population with higher education equals $9.3 \%$ and the number of students per 10,000 population - 532, as against $13.8 \%$ and 695 , respectively, for Mazovia, and $10.1 \%$ and 626 for Małopolska ${ }^{6}$. Wielkopolska displays a relatively low level of engagement of its population in lifelong learning and low investment activity of its communes.

${ }^{6}$ According to the OECD Regional Database, in 2005 the percentage of the population with higher education in Poland grew from the above 2002 figure to $15.6 \%$, while in Wielkopolska to $11 \%$ and in Mazovia to $17 \%$.
An element of the capital of applied knowledge that significantly affects the index of this dimension of competitiveness is research and development activity. On the scale of such a significant element of this type of capital as the R\&D-led practical implementation of knowledge, Wielkopolska occupies the last position in the class of the seven competitive regions. The Wielkopolska index of the capital of applied knowledge amounts to 0.14 , one-twentieth of the Mazovia figure (first position, 2.92) and much lower than the Małopolska one (second position, 1.32; Table 4). The lowest proportion of human resources in science and technology in the total population, at $17.7 \%$, shows Wielkopolska to make poor use of its scientific potential, academic base and skilled personnel in R\&D, while earmarking relatively modest outlays for R\&D, especially when compared with Mazovia and Małopolska (Table 6).

A significant element of the dimension of competitiveness in the form of infrastructure endowment and the new economy is KBE (variables 25, 27-31, and 33-35: employment in high-tech manufacturing and knowledge-intensive serv- 
TAble 6. Significant VARIABles of THE DIMENSIONS OF COMPETITIVENESS OF SEVEN REGIONS: VALUES OF THE ORIGINAL VARIABLES

\begin{tabular}{|c|c|c|c|c|c|c|c|}
\hline \multirow[b]{2}{*}{ Variable } & \multicolumn{7}{|c|}{ Region } \\
\hline & 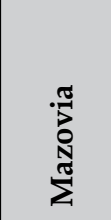 & 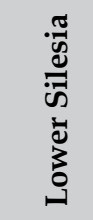 & 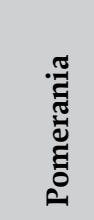 & 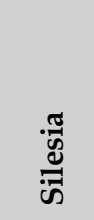 & $\begin{array}{l}\frac{\pi}{\tilde{v}} \\
\frac{0}{0} \\
\frac{0}{0} \\
\frac{\pi}{\Sigma}\end{array}$ & 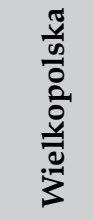 & ר్ర \\
\hline 3. Proportion of population with higher education & 13.8 & 9.9 & 10.9 & 8.9 & 10.1 & 9.3 & 9.2 \\
\hline 4. Students per 10,000 population & 695 & 583 & 449 & 402 & 626 & 532 & 550 \\
\hline $\begin{array}{l}\text { 5. University graduates who took up their first work } \\
\text { in } 2007 \text { as \% of total employment }\end{array}$ & 1.12 & 0.98 & 0.7 & 0.59 & 0.75 & 0.61 & 0.54 \\
\hline $\begin{array}{l}\text { 6. Number of persons engaged in a lifelong learning } \\
\text { programme per } 1,000 \text { population }\end{array}$ & 33 & 29 & 24 & 27 & 22 & 20 & 28 \\
\hline $\begin{array}{l}\text { 8. Non-governmental social organisations per } 10,000 \\
\text { population }\end{array}$ & 26.2 & 19.7 & 22.5 & 15.4 & 16.8 & 15.6 & 17 \\
\hline $\begin{array}{l}\text { 9. Proportion of investment outlays in communes' } \\
\text { total budgetary expenditure }\end{array}$ & 24.1 & 19.7 & 18.5 & 21.1 & 18.9 & 17.8 & 19.6 \\
\hline $\begin{array}{l}\text { 10. EU IOPRD funds granted for the years } 2004-2006 \text { as } \\
\% \text { of domestic means }\end{array}$ & 10.86 & 8.10 & 5.78 & 10.14 & 6.71 & 7.10 & 5.69 \\
\hline 14. Employment in R\&D per 1,000 working population & 9.6 & 4.6 & 5.0 & 3.3 & 5.8 & 4.6 & 3.2 \\
\hline $\begin{array}{l}\text { 15. Human resources in science and technology as \% of } \\
\text { total population }\end{array}$ & 27.3 & 20.7 & 20.0 & 19.3 & 19.1 & 17.7 & 19.2 \\
\hline 16. Outlays for R\&D per person (in zlotys) & 529 & 137 & 154 & 126 & 244 & 166 & 146 \\
\hline 17. Outlays for R\&D as $\%$ of GDP & 1.07 & 0.35 & 0.51 & 0.36 & 0.92 & 0.46 & 0.54 \\
\hline $\begin{array}{l}\text { 24. Proportion of households with personal computers } \\
\text { with Internet access }\end{array}$ & 40.5 & 36.2 & 47.0 & 42.2 & 41.8 & 36.5 & 32.5 \\
\hline $\begin{array}{l}\text { 25. Proportion of employment in very high-tech manu- } \\
\text { facturing and high-tech services (HTMh and HTS) }\end{array}$ & 5.28 & 3.17 & 4.15 & 2.97 & 2.95 & 2.54 & 2.52 \\
\hline $\begin{array}{l}\text { 27. Proportion of employment in very high-tech manu- } \\
\text { facturing (HTMh) }\end{array}$ & 1.00 & 0.60 & 1.57 & 0.52 & 0.45 & 0.50 & 0.41 \\
\hline $\begin{array}{l}\text { 28. Proportion of employment in knowledge-intensive } \\
\text { services (KIS) }\end{array}$ & 30.21 & 27.29 & 26.58 & 26.05 & 25.00 & 21.97 & 24.35 \\
\hline $\begin{array}{l}\text { 29. Proportion of employment in high-tech services } \\
\text { (HTS) }\end{array}$ & 4.28 & 2.56 & 2.59 & 2.45 & 2.50 & 2.04 & 2.11 \\
\hline $\begin{array}{l}\text { 30. Proportion of employment in business services } \\
\text { (KIMS) }\end{array}$ & 6.25 & 6.86 & 5.86 & 5.69 & 4.70 & 4.41 & 5.53 \\
\hline $\begin{array}{l}\text { 31. Proportion of employment in financial services } \\
\text { (KIFS) }\end{array}$ & 3.83 & 2.11 & 2.49 & 2.24 & 1.35 & 2.24 & 2.08 \\
\hline 33. Number of big KBE enterprises & 88 & 23 & 9 & 17 & 9 & 11 & 4 \\
\hline $\begin{array}{l}\text { 34. Big KBE enterprises as \% of total number of big en- } \\
\text { terprises }\end{array}$ & 39.82 & 52.27 & 40.91 & 32.69 & 33.33 & 25.58 & 30.77 \\
\hline $\begin{array}{l}\text { 35. Employment in big KBE enterprises as \% of employ- } \\
\text { ment in big enterprises }\end{array}$ & 51.17 & 52.36 & 76.45 & 32.85 & 25.87 & 21.09 & 21.41 \\
\hline 37. Per capita GDP (in thous. zlotys) & 44.3 & 29.7 & 27.3 & 29.4 & 24.1 & 29.2 & 25.5 \\
\hline 39. Gross value added per employee (in thous. zlotys) & 94.1 & 80.9 & 75.8 & 76.7 & 61.7 & 68.3 & 61.8 \\
\hline 43. Exports per person (in thous. euro) & 3.27 & 4.18 & 3.42 & 3.69 & 1.82 & 3.28 & 1.21 \\
\hline 44. Exports to 26 EU states per person (in thous. euro) & 2.38 & 3.71 & 2.25 & 3.19 & 1.48 & 2.73 & 0.94 \\
\hline $\begin{array}{l}\text { 45. Foreign capital per } 10,000 \text { population (in million } \\
\text { zlotys) }\end{array}$ & 123.62 & 44.22 & 14.75 & 24.54 & 31.22 & 34.43 & 14.06 \\
\hline $\begin{array}{l}\text { 46. Companies with foreign capital participation per } \\
10,000 \text { population }\end{array}$ & 43.21 & 20.84 & 17.16 & 10.83 & 9.89 & 16.11 & 9.75 \\
\hline
\end{tabular}

Source: own calculations and compilation. 
ices, big KBE enterprises). In Wielkopolska the index of the dimension of infrastructure endowment and the new economy assumes a very low value which gives the region sixth, or last but one, place (before the Łódź region) (Table 4). This low value is due not only to Wielkopolska's lowest proportion of employment in KBE in the class of the seven regions $(28.9 \%)$, but also to the region's branch structure of KBE and a small number of big KBE enterprises ${ }^{7}$ (Table 6). A specific feature of the Wielkopolska KBE branch structure is a $24 \%$ share in KBE employment of medium high-tech manufacturing, which means a relatively high contribution of this KBE subsector in comparison

${ }^{7}$ The 2008 inventory of KBE firms comes from the List of the 500 Biggest Firms published by the daily Rzeczpospolita on 29 April 2009. Those firms are treated as a sample not meeting the conditions of statistical representativeness.

TABLE 7. KBE ENTERPRISES FROM THE 2008 LIST OF THE 500 BIGGEST FIRMS IN POLAND LOCATED IN THE WIELKOPOLSKA REGION

\begin{tabular}{|c|c|c|c|c|c|c|c|}
\hline $\begin{array}{l}\text { Position } \\
\text { on List }\end{array}$ & $\begin{array}{c}\text { Name } \\
\text { of enterprise }\end{array}$ & Seat & $\begin{array}{c}\text { Form of } \\
\text { ownership }\end{array}$ & EKD & $\begin{array}{l}\text { Sales } \\
\text { proceeds } \\
\text { (in thous. } \\
\text { zlotys) }\end{array}$ & $\begin{array}{c}\text { Employment } \\
\text { (full-time } \\
\text { jobs) }\end{array}$ & $\begin{array}{l}\text { Producti- } \\
\text { vity (in thous. } \\
\text { zlotys per } \\
\text { employee) }\end{array}$ \\
\hline 23 & $\begin{array}{l}\text { Volkswagen Poznań } \\
\text { sp. z o. o. }\end{array}$ & Poznań & foreign & 3410 & $7,919,218$ & 6,133 & 1,291 \\
\hline 65 & $\begin{array}{l}\text { Philips Lighting } \\
\text { Poland SA }\end{array}$ & Piła & foreign & 3150 & $3,760,884$ & 7,230 & 520 \\
\hline 68 & $\begin{array}{l}\text { GlaxoSmithKline } \\
\text { Pharmaceuticals SA }\end{array}$ & Poznań & $\begin{array}{l}\text { foreign with } \\
\text { Treasury } \\
\text { participation }\end{array}$ & 2442 & $3,457,922$ & 1,665 & 2,077 \\
\hline 146 & Żabka Polska SA & Poznań & $\begin{array}{l}\text { private with } \\
\text { foreign capital } \\
\text { participation }\end{array}$ & 7010 & $1,837,101$ & 390 & 4,711 \\
\hline 169 & Man Bus & $\begin{array}{l}\text { Tarnowo } \\
\text { Podgórne }\end{array}$ & foreign & 3410 & $1,630,121$ & 3,775 & 432 \\
\hline 221 & Amica Wronki SA & Wronki & $\begin{array}{l}\text { private with } \\
\text { foreign capital } \\
\text { participation }\end{array}$ & 2971 & n.d. & n.d. & n.d. \\
\hline 223 & Nivea Polska & Poznań & foreign & 2452 & $1,223,099$ & 545 & 2,244 \\
\hline 240 & $\begin{array}{l}\text { GlaxoSmithKline } \\
\text { Services }\end{array}$ & Poznań & foreign & 2910 & n.d. & n.d. & n.d. \\
\hline 261 & $\begin{array}{l}\text { Solaris Bus \& Coach } \\
\text { SA }\end{array}$ & Owińska & private & 3410 & $1,043,626$ & 1,545 & 675 \\
\hline 374 & Grupa HCP SA & Poznań & Treasury & 2911 & 652,106 & 2,777 & 235 \\
\hline 441 & $\begin{array}{l}\text { Exide Technologies } \\
\text { SA }\end{array}$ & Poznań & $\begin{array}{l}\text { foreign with } \\
\text { Treasury } \\
\text { participation }\end{array}$ & 3140 & 494,107 & 422 & 1,171 \\
\hline
\end{tabular}

Source: The 500 List. The biggest firms of the Republic, 2008. Rzeczpospolita, 29 April 2009. 
with the other regions, and a relatively low contribution of knowledge-intensive services, including high-tech services.

In 2008 there were 11 big KBE enterprises (according to the 500 List) in Wielkopolska, which gave the region 4th position (behind Mazovia with 88 firms, Lower Silesia with 23, and Silesia with 17) (Table 6). They accounted for a mere $25 \%$ of all the big firms located in the region. Ten KBE enterprises represented medium high-tech industries: the chemical industry, electrical machine and equipment building, mechanical machine and equipment building, and the motor vehicle industry (Table 7). The region had only one big service firm classed as KBE. There were no big firms offering high-tech services, including information services ${ }^{8}$. Seven KBE firms located in Wielkopolska were foreign-owned, with three of them belonging to those most valuable in Poland (GlaxoSmithKline Pharmaceuticals, Volkswagen, and Philips Lighting Poland, estimated at more than 1.5 billion zlotys). Volkswagen, Philips Lighting Poland, GlaxoSmithKline Pharmaceuticals, and Man Bus - Tarnowo Podgórne represented the biggest exporters in Poland (with the share of exports in their sales amounting to $86 \%, 88 \%$, $64 \%$, and $100 \%$, respectively). The productivity of big KBE firms in Wielkopolska was high when compared with the average for big KBE firms in Poland, and amounted to $150 \%$ (as against $92 \%$ in Mazovia and $120 \%$ in Silesia).

Wielkopolska stands relatively high on the scale of the index of the fourth dimension of competitiveness, viz. economic performance. The region occupies third place after Mazovia and Lower Silesia. It is worth remembering that on the scale of factors of competitiveness Wielkopolska only ranks sixth or seventh, viz. the last in the class of the seven regions (Table 4).

The index of economic advantages generated by a region's factors of competitiveness is made up of the following variables: per capita income, productivity of labour, exports, and foreign

${ }^{8}$ In the years 2003-2004 the number of big KBE firms in Wielkopolska voivodeship on the 500 List amounted to ten (only manufacturing, industrial firms), seven of which were also listed in 2008. It should be noted at this point that in Wielkopolska the first clear symptoms of development of telecommunications and information firms appeared as early as 2004, but businesses operating in this sector are largely medium-sized ones. capital (variables 37, 39, and 43-46). In Wielkopolska, per capita income amounted to 29,000 zlotys (2006) and was close to that in Silesia and Lower Silesia, and lower only than the Mazovia figure (Table 6). In terms of the productivity of labour, Wielkopolska occupies only fifth place in the class of the seven regions (with gross value added per employee of 68,000 zlotys). In terms of exports per person $(3,28,000$ euro), it occupies the same position as Mazovia, Pomerania and Silesia, but lower than Lower Silesia and higher than the regions of Łódź and Małopolska. As to exports to EU per person, it comes third, after Lower Silesia and Silesia. The level of foreign capital per 10,000 population (3,400,000 zlotys) gives Wielkopolska third place (behind Mazovia and Lower Silesia), and its 16 companies with foreign capital participation per 10,000 population, fourth place (behind Mazovia, Lower Silesia and Pomerania).

Thus, what we have in Wielkopolska is a situation in which the low competitive potential of the region in terms of KBE co-occurs with relatively high economic performance that it enjoys ${ }^{9}$.

\section{Final remarks}

When assessing the cognitive value of the presented diagnosis of the competitiveness of the Wielkopolska region, the following methodological and empirical issues should be taken into account.

(1) The model of a region's competitiveness employed in the paper rests on the assumption that today it is KBE that provides a basis for the region's competitive advantage. However, Poland has a poorly developed knowledge-based economy. The chief region of KBE development in Poland is Mazovia. In the remaining regions with urban agglomerations, including Wielkopolska, the share of KBE in their economies is low.

(2) In the empirically concretised model of competitiveness of Wielkopolska, economic advantages treated as effects of the competitiveness turned out to be higher than implied by the region's position on the scale of KBE-derived competitive potential. This can be explained as follows. The level of regional income - the basic

\footnotetext{
${ }^{9}$ Worth noting is the fact that a reverse situation occurs in Małopolska.
} 
effect of competitiveness - is not solely determined by KBE. It is also generated by enterprises of the traditional sectors that predominate in the Wielkopolska economy. The relatively high level of effects of competitiveness in relation to the competitiveness base in the form of KBE means that KBE makes a small contribution to the competitiveness of the Wielkopolska region.

(3) The structure of the region's economy as a condition determining its competitiveness should be understood as a subsystem of production and services which includes new or restructured enterprises, or those that supplement it and fill in gaps in its economic activity, or that give it new growth impulses (Chojnicki \& Czyż 2005: 14). Those new impulses are generated primarily by KBE enterprises that introduce new, advanced technologies into it. Thus, a measure of an increase in the region's competitive position is the emergence in it of new structural KBE-related systems that guarantee the region steady development (Klamut \& Passella 1999: 60). Is this the path of change in the economic structure that is characteristic of the Wielkopolska region?

Wielkopolska as a region with a relatively high per capita income has a considerable share of services and industry in its economic structure: services account for $60 \%$, and industry for $32 \%$ of gross regional income generated (in 2006). However, predominant in both industry and services are the traditional branches of low innovativeness employing medium-skilled personnel. Wielkopolska industry largely manufactures "non-modern products" (Chmielewski et al. 2001: 94-96) ${ }^{10}$. A weak side of the Wielkopolska economy is its low advancement as expressed by the small share of firms representing very high technology. In innovative activity the emphasis is put primarily on modernisation of the technological backup. While Wielkopolska stands out for its well-developed business environment and services, its networks of co-operation between the economy and the regional $R \& D$ institutions are poorly developed (Dominiak 2006: 150). The carriers of innovation are big enterprises, while the role of small and medium-sized firms is insignificant. Even with the large contribution of foreign capital to the re-

${ }^{10}$ The production of foodstuffs in Wielkopolska contributes $25 \%$ to the region's value of industrial production sold (2006). gion's economy, foreign enterprises are of little importance as sources of innovation diffusion because the technological gap hinders the formation of local co-operation networks ${ }^{11}$.

(4) The Wielkopolska region displays low modern-type competitiveness owing to the insufficient advancement of its economy (Wojtasiewicz 2004: 55). To meet new challenges in the process of formation of its competitiveness, an important direction of change in the regional economy is the transformation of its structure through KBE development. The factors determining KBE development in the region should be an increase in innovativeness as a result of a more rational operation of the Regional Innovation System, and the establishment of an intra-regional, network-like type of organisation of its economic activity in the form of clusters.

(5) Finally, it should be observed that the position of Wielkopolska in the national ranking of competitiveness was established with the help of a model ignoring the traditional factors of competitiveness characteristic of the region (Wojtasiewicz 2004: 54). Among them is the geographical location of the region. Another weakness of the analysis is the absence of a broader treatment of the properties of social capital (in the sense of norms or values of interpersonal relations that make co-operation possible), which is an important factor contributing to the competitiveness of the Wielkopolska region. The reason for the omission is difficulties with measurement and a gap in the regional statistical bases.

\section{References}

BinIECKI J. \& FRENKIEL W., 2005. Konkurencyjność - przedsiębiorczość - rozwój: podstawowe dylematy pojęciowe i metodyczne. Biuletyn KPZK PAN, 218: 23-46.

Chmielewski R., Stryjakiewicz T., Twardowska J. \& WALOSZCZYK J., 2001. Innowacyjność przemysłu i jej zróżnicowanie w układzie wojewódzkim. Biuletyn KPZK PAN, 197: 59-101.

Chojnicki Z. \& Czyż T., 2005. Rozwój społeczno-gospodarczy w ujęciu regionalnym. Biuletyn KPZK PAN, 219, Warszawa, 8-23.

Chojnicki Z. \& Czyż T., 2006. Aspekty regionalne gospodarki opartej na wiedzy. Bogucki Wydawnictwo Naukowe, Poznań.

${ }^{11}$ An example of favourable changes taking place in the impact of foreign enterprises on technological advancement in Wielkopolska can be the activity by Volkswagen (Wdowicka 2009: 80-81). 
DOMINIAK J., 2006. Struktura i organizacja przestrzenna otoczenia biznesu w aglomeracji poznańskiej. Bogucki Wydawnictwo Naukowe, Poznań.

GacZeK W. M. \& RYKIEL Z., 2000. Konkurencyjność regionów a ich adaptacyjność. In: S. Ciok, D. Ilnicki (eds), Przeksztatcenia regionalnych struktur funkcjonalno-przestrzennych. Uniwersytet Wrocławski, Wrocław: 113-128.

Gardiner B., Martin R. \& Tyler P., 2004. Competitiveness, productivity and economic growth across the European regions. Regional Studies, 38(9): 1045-1067.

Huggins R. \& DAvies W., 2006. European Competitiveness. Retrieved March 10, 2010, from http://www.hugginsassociates.com/

Kitson M., Martin R. \& Tyler P., 2004. Regional competitiveness: an elusive yet key concept? Regional Studies, 38(9): 991-999.

Klamut M. \& Passella E., 1999. Podnoszenie poziomu konkurencyjności regionów. In: M. Klamut (ed.), Konkurencyjność regionów. Wydawnictwo Akademii Ekonomicznej im. O. Langego we Wrocławiu, Wrocław: 57-83.

KLASIK A., 2003. Strategie konkurencyjne polskich regionów. Biuletyn KPZK PAN, 204: 63-79.

Lista 500. Największe firmy Rzeczpospolitej. (2008, April 29). Rzeczpospolita.

MaćKieWicz A., Ratajczak W., 1993. Principal components analysis (PCA). Computers and Geosciences, 19(3): 303342.

MARKowsKi T., 2005. Przedmiotowa i podmiotowa konkurencyjność regionów. Biuletyn KPZK PAN, 219: 24-37.

PORTER M.E., 1990. The competitive advantage of nations. Macmillan, London.
Porter M.E., (tł. polskie) 2001. O konkurencyjności. Polskie Wydawnictwo Ekonomiczne, Warszawa.

RATAjCZAK W., 2007. Competitiveness of Polish regions and ecodevelopment. $2^{\text {nd }}$ Central European Conference in Regional Science - CERS. 2007. Technical University of Košice, Faculty of Economics, Košice: 834-846.

RATAJCZAK W., 2008. Innowacyjność a konkurencyjność polskich regionów. In: J. J. Parysek, T. Stryjakiewicz (eds), Region społeczno-ekonomiczny i rozwój regionalny. Bogucki Wydawnictwo Naukowe, Poznań: 299-313.

StryjaKiEWicz T., 1999. Adaptacja przestrzenna przemystu $w$ Polsce $w$ warunkach transformacji. Wydawnictwo Naukowe UAM, Poznań.

WDOWICKA M., 2009. Ewolucja działania korporacji transnarodowych i jej znaczenie w gospodarce lokalnej. Biuletyn Rozwój Regionalny i Polityka Regionalna, 6: 62-86.

WINIARSKI B., 1999. Konkurencyjność: kryterium wyboru czy kierunek strategii i cel pośredni polityki regionalnej? In: M. Klamut (ed.), Konkurencyjność regionów. Wydawnictwo Akademii Ekonomicznej im. O. Langego we Wrocławiu, Wrocław: 9-19.

WojtAsiEWicz L., 2004. Konkurencyjność gospodarki Wielkopolski w świetle wyzwań XXI wieku. In: W. Molik, A. Sakson, T. Stryjakiewicz (eds.), Wielkopolska wobec wyzwań XXI wieku. Centrum "Instytut Wielkopolski”, Uniwersytet im. A. Mickiewicza, Poznań: 49-64.

WORONIECKI J., 2001. Nowa gospodarka: miraż czy rzeczywistość? Doktryna, praktyka, optyka OECD. In: Gospodarka oparta na wiedzy. Wyzwanie dla Polski XXI wieku. Komitet Badań Naukowych, Warszawa: 47-79. 